\section{Epistemological resistances and the search for alternatives to modernity in intellectual history}

\author{
Resistencias epistemológicas y la búsqueda de alternativas a la modernidad en la histo- \\ ria intelectual
}

Dennis Stromback

\begin{abstract}
The violence of modernity has led to epistemological resistances around the world and the search for alternative ways of reconstructing philosophy. Among the Frankfurt School and early Kyoto School thinkers, for instance, the problem of modernity is framed as an excess of objective rationality, but among the decolonial thinkers of Latin America, the problem is conceptualized as the very myth of modernity itself that has legitimized the colonization and exclusion of non-Europeans. In the search for alternatives, the Kyoto School and Latin American philosophy concur on a vision of inter-civilizational dialogue, which amounts to an engagement of alterity or differences, whereas the Frankfurt School, albeit struggles to find consensus on how to overcome modernity, aims to merely preclude the problem of reproducing the impulses toward the domination of oneself and others. Nonetheless, all these paradigms have a theoretical point of convergence: that is, since we are all participants of modernity, we are both victims and executioners of its violence, and thus compelled to negate it. This article will discuss how the violence of modernity is experienced, theorized, and then challenged around different continents in order to make visible not just how the violence of modernity is reproduced in different ways but also to force ourselves to engage in self-critique in the pursuit to make explicit our own assumptions that repeat the violence of modernity.
\end{abstract}

Keywords: Modernity; Kyoto School; the Decolonial Critique; Frankfurt School; Eurocentrism

\section{RESUMEN}

La violencia de la modernidad ha provocado resistencias epistemológicas en todo el mundo, así como la búsqueda de formas alternativas de reconstruir la filosofía. Entre los pensadores de la Escuela de Frankfurt y de la primera Escuela de Kioto, por ejemplo, el problema de la modernidad se enmarca como un exceso de racionalidad objetiva, pero entre los pensadores decoloniales de América Latina, el problema se conceptualiza como el propio mito de la modernidad que ha legitimado la colonización y la exclusión de los no europeos. En la búsqueda de alternativas, la Escuela de Kioto y la filosofía latinoamericana coinciden en una visión de diálogo intercivilizacional, lo que equivale a un compromiso con la alteridad o las diferencias, mientras que con la Escuela de Frankfurt, aunque se esfuerza por encontrar un consenso sobre cómo superar la modernidad, se propone simplemente excluir el problema de la reproducción de los impulsos hacia la dominación de uno mismo y de los demás. No obstante, todos estos paradigmas tienen un punto de convergencia teórico: es decir, que como todos somos partícipes de la modernidad, somos a la vez víctimas y verdugos de su violencia, y por tanto estamos obligados a negarla. Este artículo analizará cómo se experimenta, se teoriza y se cuestiona la violencia de la modernidad en diferentes continentes, con el fin de hacer visible no sólo cómo se reproduce la violencia de la modernidad de diferentes maneras, sino para obligarnos a hacer una autocrítica en la búsqueda de explicitar nuestros propios supuestos que repiten la violencia de la modernidad.

Palabras clave: Modernidad; Escuela de Kioto; Crítica Decolonial; Escuela de Frankfurt; Eurocentrismo

\section{INFORMATION}

https://doi.org/10.46652/resistances. v2i4.56

ISSN 2737-6222 |

Vol. 2 No. 4, 2021, e21056

Quito, Ecuador

Submitted: August 02, 2021

Accepted: October 26, 2021

Published online: November 24, 2021

Continuous publication

General Section | Peer Reviewed

\section{AUTHOR}

Dennis Stromback Independent Scholar - United States dstromb3@gmail.com

Conflict of interest

No potential conflict of interest is reported by the author. Funding

No financial assistance from parties outside this article.

Acknowledgments $\mathrm{N} / \mathrm{A}$

PUBLISHER

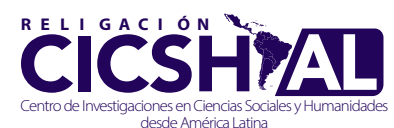




\section{Introduction}

While destruction and terror has always been a part of human life, there is something more unique about what we might call the "violence of modernity." Rooted in the culture itself, the violence of modernity, interestingly enough, takes on the face of reason, justice, and morality in the service of exclusion and control. But what makes this a plausible venue of investigation is that there have been epistemological resistances from around the world (from three, or arguably four, different continents) that have occurred resistances search for an alternative correct the failures of the modernist narrative constructed by the European imagination characterizing itself as the cultural and philosophical zenith of civilization. In the North American and European continents, there is the entire post-modern tradition seeking to dethrone its own home-grown universal rationality established during the Enlightenment, meanwhile in Asia and Latin America, there is the Kyoto School and the decolonial critique (as one aspect of Latin American philosophy), respectively, who are also seeking to destabilize the modernist project but with a more specific goal of establishing philosophical pluralism. Is this disenchantment with modernity a mere coincidence? Or is there something innately problematic about the modernist experiment-as in, a problem that is clearly visible from both inside and outside of the political centers of modernization?

What can be said here is that a revolt against modernity was likely in the cards, especially given Hegel's totalizing account of world history, which set the stage for an abuse of rationality in the name of freedom, truth, and progress. Embedded in Hegel's corpus is a geo-cultural racism that placed Asia, Africa, and the natives of the Americas in the lower rungs of human existence, reserving spirit for European white men. Hegel (1978) himself alludes to this as such in the Philosophie des subjektiven Geistes [Philosophy of Subjective Spirit]:

It is in the Caucasian race that spirit first reaches absolute unity with itself. It is here that it first enters into complete opposition to naturality, apprehends itself in the absolute independence, disengages from the dispersive vacillation between one extreme and the other, achieves self-determination, self-development, and so brings forth world history.... It is, the concrete universal, self-determining thought, which constitutes the principle and character of Europeans. (pp. 57-60)

What all of this tells us is that, as Teshale Tibebu (2011) suggests, is that modernity can be thought of as both a positive and negative project: in terms of the positive aspect, there have been some cultural and material "progress" for some in the global north, but the negative aspect are the events and legacies of the three pillars of modernist violence: the American Holocaust, New World slavery, and colonialism ( $\mathrm{p} . \mathrm{xvi}$ ). While we can add a fourth event and legacy - the destruction and annihilation of the ecological environment, the point nonetheless is that Western modernity, and its propagation around the world, is far from being a successful project for everyone. In fact, the reification of the category of "progress" has generated false promises as well as provided the rhetorical material for naturalizing systems of power in the interests of ruling classes; and so, when the "benefits" of "progress" are not distributed equitably, then naturally there is resistance and pressure for alternatives.

Charles Baudelaire once described the violence of modernity as a willingness to be both a victim and an executioner. One might interpret this as a witness to the deep trauma of modernity, but 
it also can be read as a self-critique of one's participation in violence (Sanyal, 2006, p. 6). The purpose of this article is therefore to investigate the different epistemological resistances from around the world, from the Frankfurt School to the Kyoto School of Japan and the decolonial critique from Latin America, the decolonial critique from Latin America, to reveal how all of these voices from different continents represent not only the limits, problems, and struggles of modernity but how to address its cultural, structural, and philosophical violence, but in a way that sustains the Baudelairean critique. Of course, there is just too much ground to cover for a short article, and so as a result, this discussion will only focus on a few philosophers from within the three schools of thought who are determined to subvert Western modernity in order to assert their own epistemological alternative. As will be seen, not all of these schools of thought agree on what the central problems are with modernity, but they all recognize the failure of this grand experiment itself, particularly around the expansion of capitalism and the deployment of objective reason (and its concomitant category of linear progress), because of the abuses that have arisen therefrom.

Indeed, there is a lot to learn from the arguments presented against modernity, not just from the interior, like in the case of the Frankfurt School, but from the exterior as well (like in the case of the Kyoto School and the decolonial critique of Latin America), especially because the voices external to the center of Western modernity have mostly been overlooked not just by the postmodernist and modernist alike, but also by those who seek to overcome these two totalizing systems of thoughts from within the interior (e.g., the post-Marxists). What Western intellectual thought cannot see is what the external critiques see and so what is invisible to the paradigms of Western thought becomes an important asset for making visible the internal critiques and violence of modernity. Japanese Kantian-Marxist Kōjin Karatani (2003) claims that the point of a radical critique is to discern the irreducible gap between structural positions so as to "face reality that is exposed through difference (parallax)" (p. 14). And so, in pursuit of Karatani's radical critique, by exposing the differences between the structural positions posed against modernity, this article will be able to discern myriad forms of violence that are both visible and invisible at the center as well as at the periphery, that which imprisons existence within a state of being that is both a victim and an executioner of violence. In short, what we will discover from this intellectual tapestry, in this aim to tease out these structural differences, is the continued need for a particularized global world-namely, the voices of the subaltern, of those who have been excluded from modernity, to critically reflect on being both the victim and executioner of the violence of modernity from an epistemological standpoint in order to bring forth alternative visions of how to rebuild the world.

\section{The European Revolt: the Frankfurt School}

It is often said that the origins of the postmodern critique began with the Frankfurt School. In 1947, Max Horkheimer published "Die Revolte der Natur" [the Revolt of Nature], which was another pivotal moment in the demythologization and disenchantment of human history (alongside the previous demythologization and disenchantment of traditional religious life), but such demythologization and disenchantment were derived more from the unmasking of the fetish to control and dominate the natural world through objectified reason and scientific technology. Horkheimer introduces a powerful critique against the violence of instrumental reason in this 
article, revealing the contradictions of a burgeoning rational society brought forth by capitalism. While rationality is thought to have liberated humanity from the irrational forces of darkness and superstition, the opposite has been the case: rationality has led to more calculated forms of domination. Horkheimer writes:

\begin{abstract}
The human being, in the process of his emancipation, shares the fate of the rest of his world. Domination of nature involves domination of man. Each subject not only has to take part in the subjugation of external nature, human and nonhuman, but in order to do so must subjugate nature in himself (1985, p. 94).
\end{abstract}

What is important to note here is that Horkheimer draws on both Marx and Freud with the claim that society's growing conformity to the rational, pragmatic demands of economic forces has forged a repression of human nature in the form of a revolt against society. That is to say, while Horkheimer, like other theorists of the Frankfurt School, deploy Freud and psychanalytic theory in order to make up for the deficiencies of Marxist theory, namely, this tendency to reduce the psychological realm to socio-economic structures (Whitebook, 2006, p. 74), the fundamental point here, in terms of understanding Horkheimer's critique of modernity, and perhaps the Frankfurt School's critique as a whole, is that socio-economic structures can never eradicate human nature, or natural impulses rather, and so nature must revolt as a response to the repression generated by socio-economic structures.

Horkheimer, along with another important figure of the Frankfurt School, Theodor Adorno, in the "Dialektik der Aufklärung" [the Dialectic of the Enlightenment] (2019) describe this movement of disenchantment with objective rationality as a dark reversal, as a "sinking into a new kind of barbarism" (p. 1). Just as there is progress in the Enlightenment, there are also ruptures and reversions into regression, which for Horkheimer and Adorno is best exemplified by the horrors of fascism and the ability of fascist states to cast their agenda as reasonable. In the end, there is a paradox to the dialectical structure of the Enlightenment: that "myth becomes Enlightenment" (Horkheimer \& Adorno, 2019, p. 15) when "Enlightenment is totalitarianism" (Horkheimer \& Adorno, 2019, p. 12). But even lurking beneath these fascist arrangements was already the kernel of domination fostered by the Enlightenment desire to root out the unknown (Horkheimer \& Adorno, 2019, p. 35). What is different and unintelligible to the Enlightenment was interpreted as an enslavement to the natural world; therefore, in the pursuit to destroy these mythic forces of the world, the Enlightenment was determined to convert knowledge into power in the service of subjugating and controlling the unknown in order to emancipate the self from nature. The consequence of this pursuit lead to a reification of reason that would install humanity as the masters of the world (Horkheimer \& Adorno, 2019, pp. 43-49).

Horkheimer rests the blame of Enlightenment barbarism mostly on pragmatism and positivism for having subjectivized formal reason and instrumentalizing all thought. Here, Horkheimer makes an important distinction between objective reason and subjective reason. While the former refers to universal truths associated with a kind of reasoned morality, the latter refers to the abstract form of thinking that is mostly concerned with how to maintain and maximize self-preservation (Horkheimer, 1985, pp. 16-22). With no concern for the end goal or purpose, as Horkheimer argues, subjectivized reason calculates the cost of action on the basis of inference, 
deduction, or classification, to the point where "its operational value, its role in the domination of men and nature, has been made the sole criterion" (1985, p. 30). In this regard, efficiency becomes the idealized outcome of our actions within subjectivized reason because we determine things on ground of its usefulness. But reason begins to work against itself, as Horkheimer maintains, when the irrationality of our actions become rationalized, when reason "lends itself to ideological manipulation and to the propagation of even the most blatant lies" (1985, p. 33). While many have criticized Horkheimer for misunderstanding pragmatism, there is something to his critique of positivism and its subjectivization of reason in modernity: that the reduction of rationality to a subjectivized logic of instrumentalization has furnished the ideology of market apparatuses.

Horkheimer and Adorno, expounds on this absorption of rationality into the ideological marketplace in the "Kulturindustrie" [the Culture Industry]. According to Horkheimer and Adorno, the industries of entertainment function as forms of domination within capitalist societies because they operate as mass deception. Although it seems as if humanity is free from the demands of work while engaged in mass consumerism, the reality is that these industries deny any sense of real freedom by impeding the development of a critical consciousness necessary for making explicit how culture is commodified and how subjects are turned into objects of capital production as culture becomes an industry generating profit (Horkheimer \& Adorno, 2019). In short, subjectivity becomes pacified consumers in the culture industry. Like Horkheimer's analysis of how subjectivity dominates itself through its fetishization of reason in "Die Revolte der Natur," Horkheimer and Adorno in "Kulturindustrie" claim that the domination of human nature is the result of capitalism mass producing culture through a rationalized system of techniques. Culture becomes homogeneous, formulaic, and repetitive because the mechanistic nature of the production, distribution, and consumption process itself is economically rationalized (Horkheimer \& Adorno, 2019). In both Horkheimer's and Adorno's account of a mechanized modernity is a subjectivity that has little room for genuine freedom in a capitalist society dominated by instrumental rationality.

Bleaker than Horkheimer's and Adorno's view is Herbert Marcuse's argument which maintains that social control and repression are in fact central features of the system of production and consumption of mass entertainment where thought and behavior become "one-dimensional" because of the erosion of critical consciousness, leaving only those "false needs" that have been manufactured by industrial capitalism (1991, pp. 1-12). According to Marcuse, while we think we live in a democratic society, it is actually totalitarian because technological rationality has penetrated every aspect of our public life and culture to the point of withering the distinction between them (1991, pp. 3-5 \& pp. 16-18). This is because there is a shared logic of domination within both a totalitarian society and an espoused democratic capitalist system: that is to say, the system itself has prepared subjectivity to think of itself as freer than what it actually is just as long as it is provided with enough needs to stay pacified. When subjectivity becomes onedimensional, such contradictions are made invisible, bringing subjectivity to even identify with the oppressor (Marcuse, 1965; 1991). As society becomes more and more one-dimensional, there even becomes an ever-greater threat of what Marcuse (1965) calls "repressive tolerance" which is this inversion of the oppressed becoming the oppressor within a "free society" where the ideas and concepts that are believed to liberate people are co-opted by other dominant forces to 
legitimate oppression. Note that Marcuse, Adorno, and Horkheimer have a lot in common here: all recognize that the Enlightenment, albeit declared to be a project of liberation, embodies systems of repression and domination by virtue of how rationality is deployed. Therefore, modernity is not an emancipation from the past or a progressive stage in the evolution of thought, but a new age of darkness and terror, generated in part by the expansion of industrial capitalism.

Of course, it is not fair to say that the Frankfurt School is uni-vocal in its quest to destabilize the Enlightenment. Although Marcuse comes off as the most pessimistic of the Frankfurt School, the opposite is actually the case: for Marcuse, there is liberatory potential in revolutionary movements that seek to create positive social change through the resistance against the repression and domination motorized by industrial capitalism. We can rid the systems of domination within society by redefining subjectivity - to replace this repressed subjectivity with a wholly new form of subjectivity (see Marcuse, An Essay on Liberation, 1969). Here we can see that Marcuse is quite different than the other Frankfurt School thinkers because there is a renouncing of the working class in terms of operating as a revolutionary subject. The New Left of the 1960s, which Horkheimer opposed, was in many ways fueled by Marcuse's look to identity politics as forms of resistance and social transformation. The Francophone thinkers-Deleuze, Foucault, Lyotard and so on-that influenced the postmodern turn would not have trouble finding some common ground in these cultural and identitarian movements, because all these thinkers look to radicalize subjectivity in the form of political resistance. But a backlash against Marcuse and the New Left certainly exists today as well: as the criticism goes, a focus on a new form of subjectivity that removes the framework of class has lent itself to the oppressions of global capitalism because it does not redefine subjectivity in a way that goes beyond the ensemble of relations existing at the heart of material production (see Eagleton, 2003, see also Sanbonmatsu, 2004). In other words, the irony of Marcuse's view of political resistance is that such easily becomes complicit with the forms of domination generated by capital accumulation because it advances the struggle against modernity within discourses that legitimize capitalism-hence it is possible for wealthier racial and feminist subjects, despite their own struggle for political equality, to abandon the plight of the poor.

In any event, Horkheimer and Adorno did not have what Marcuse had in mind. While there is some revolutionary program in Marcuse's critical theory, Horkheimer and Adorno mostly saw a renouncing of rationality as a means for social change. As Horkheimer (1985) most famously wrote:

If by enlightenment and intellectual progress we mean the freeing of man from superstitious belief in evil forces, in demons and fairies, in blind fate-in short, the emancipation from fear - then denunciation of what is currently called reason is the greatest service reason can render (p. 174).

But there is a divide in terms of how the problem of technical rationality is approached in Horkheimer and Adorno-the latter being the most dystopian of the Frankfurt School. Contra Adorno, Horkheimer looked to religion to alleviate the violence of modernity. Since the future is open ended, as Horkheimer believes, critical theory must use negativity in a way that focuses 
on the concrete suffering of the innocent victims of modernity, without seeking to establish a positive result as such. But religion can assist this historical struggle for a better future and help society avoid a rebarbarization by providing critical hope and motivation for empowering subjectivity (Ott, 2001). The anachronistic forms of religion, which have served the systems of domination in history, must be negated in Horkheimer's critical theory, but if religion can provide revolutionary potential in a secular form, that which is relevant to the appropriate social-historical situation, then subjectivity can continuously uproot the conservative aspects of religion and redirect humanity's cry of misery and hope for justice and happiness back to the problems of capitalism and those who suffered from the fetish of technical rationality (Ott, 2001).

Is there anything we can learn from the Frankfurt School's critique of modernity? As we move into the next sections, we will find similar grievances and complaints against modernity, but with more interest in "overcoming" it-in particular, its "European-ness." Such an angle will therefore provide us with a lens that can expose some of the limitations of the Frankfurt School's critique. For instance, the visions asserted by these thinkers in the attempt to address modernist despair does not contain a renunciation of rationality, as espoused by many Frankfurt School thinkers, but rather the need for more rationality or logic in totally different forms-more specifically, forms that are more historical, contextual, and dialogically grounded. In this sense, the Frankfurt School's critique reflects a certain Eurocentric take on modernity not only because it relies on a view of human nature (borrowed from psychoanalysis) that is European at its origins, but because it fails to recognize and incorporate these alternative forms of rationality or logics that are culturally informed, that which could be used for local resistance and "overcoming" the problems and limits of modernity.

In spite of the similar theoretical gestures on these different continents, there is an originality to the Frankfurt School nonetheless, which is this attempt to understand the psychological disposition toward totalitarian governance in an age where reason is thought to be the mode of social, political, and cultural criticism. Especially today, where there is an ever-present slippage toward totalitarianism, the Frankfurt School can be helpful in the elucidation of how and why subjectivity is prone to become participants of modernist violence, where victims become supporters or actors of oppression. Unfortunately, in the era of radical right-wing populism, we are seeing this Frankfurt nightmare becoming a reality: not just in terms of the working poor defending the violence and oppression of the major figureheads of neo-liberal capitalism but in terms of the dystopia that is already being made visible because of an absence of a clear alternative to capitalist visions of the world. There is a tension between post-Marxism, with Slavoj Žižek and Alain Badiou on one end, and political identitarianism, with Judith Butler and the Foucauldians on the other, that has yet to be worked out systematically. Marcuse's account of liberation may still have sway in the zeitgeist of global protesting, but a political movement geared toward manifesting a particular emancipated future fails to gain much traction because many of these alternatives have either been marked or written off as historical failures or have yet to clarify an ideological alternative that addresses the deeper structures catalyzing the forms of violence in the benefit of all subjectivities. What is left-over is just the hope to empower marginalized subjectivities in a neo-liberal world that is on the brink of totalitarian rule. Is a return to a Marxist subjectivity the proper medicine for this historical moment? Can this new Marxist subjectivity intermingle 
smoothly with the critiques and concerns of race, ethnic, feminist, and gender scholars in a way that present a clear alternative for the emancipation of everyone? An answer to these questions is beyond the scope of this article, but if we return to the Baudelairean self-critique posed at the beginning of this article and fasten this self-critique to Karatani's radical critique, then we need to examine what is invisible to the Frankfurt School by making explicit its own philosophical assumptions of the world so that we can better understand how this critique still participates in the violence of modernity and how we can advance an alternative that corrects the limits of the Frankfurt School without jettisoning its central concerns and insights. In order for this to be possible, we have to move toward the exterior and investigate modernity from that standpoint.

\section{The Japanese Revolt: the Kyoto School}

In the article, “The Problem of Japanese Culture” (Nihon bunka no mondai 日本文化の問題), Japanese philosopher Nishida Kitarō (1870-1945) discusses, among other things, the problem of world history from the standpoint of the Occident. Nishida saw that the Occidental worldview is one where Europe places itself at the apogee of evolutionary progress while Asia is positioned at a lower stage of cultural development. Of course, the problem with the European framing of world history, as Nishida holds, is its assumed cultural hierarchy, that which subordinates Asian religions and thought. As Nishida (1965, vol. 12) laments,

On this basis they [Europeans] conceive of stages of cultural development, in terms of which Oriental culture is seen as still lingering in an undeveloped stage. Oriental culture must, if developed, become identical with the Occidental one, they believe. Even such a great thinker as Hegel shared this view (p. 284).

As one would expect, Nishida's response was to resist this view of cultural history and demonstrate why Asia not only has its own intellectual heritages that not only matches the rigor of Occidental thought but also how it radiates a logic, particularly its religious logic, that cannot be accounted for in the Occidental world (Stromback, 2020, pp. 77-80). In fact, as the founder of the Kyoto School, Nishida began philosophical inquiry on the basis of challenging the subject-object relationship metastasizing the epistemology of Western modernity, which would set in motion a new lineage of intellectual history that began in late Meiji and early Taishō Japan. Naturally, Nishida's work evolved overtime, but all throughout his oeuvre was a determination to reconfigure the epistemological foundations of (Western) philosophy and to put forth an alternative standpoint of knowledge that is more inclusive of other cultural and intellectual histories. This "alternative standpoint," which was based on uniting the subject and object, would allow for creating an "inter-civilizational logic" that transcends the cultural particulars of East and West. This is the beginning of the Japanese revolt against Western modernity.

One way to assert oneself in philosophy is by appropriating the language of the master and to rebuild the language from the ground up. Nishida did precisely this. As both a Hegelian and a Buddhist, Nishida revised the concept of dialectical logic by reinterpreting its structural dynamic. Contra Hegel, who saw the movement of the dialectic in more temporal terms, Nishida saw the movement in more spatial terms. What we do not see in Hegel's dialectic is what we see in what 
Nishida calls "the logic of absolute contradictory self-identity" (zettai mujun-teki jikodōitsu no ronri 絶対矛盾的自己同一の論理): that a true absolute is the self-contradiction itself and not the monistic One that is beyond contradictions (via synthesis). In other words, the affirmation of an identity only arises within a place of self-negation. Both Hegel and Nishida made good use of a logic of negativity in the attempt to clarify their dialectical structure, but there is a locus for all that exists in the world in Nishida's dialectics, a locus that provides the structural ground for both affirmation and negation as a bilateral movement (Zimmermann, 2006, p. 187). The tripartite process of the dialectic in Hegel's philosophy is now converted to that of a thesis is antithesis and antithesis is thesis in Nishida's philosophy. This is all to say that there is a teleological structure to Hegel's dialectics due to an absence of a logic of place (as well as his inauguration of Aristotle's logic of substance), where the process of overcoming tends to stay put in one (linear) direction, while the movement in Nishida's dialectics exist in the place itself, which means that the movement continuously flows forward and backwards in a vertical direction. It is impossible at that point to assert a linear teleology without reifying one's own intellectual standpoint.

What makes Nishida's reinterpretation of the dialectic an act of cultural and philosophical resistance is the way in which he applies it to the historical world. No longer is progress a cultural and intellectual movement that builds and evolves over time, solidified in stages of development, but rather an internal deepening of self-awareness within a cultural particular upon confronting its own self-contradictions. Nishida's vision of a “global world” (sekaiteki sekai 世界的世界) instantiates this unfolding of the contradictory logic as a place dialectic: that is, a world historical space based on cultural particulars seeking to realize their own contradictory identity. What this vision looks like is more of an interactive web of cultural particulars engaging in dialogical transformation and mutual differentiation, because a cultural particular realizing its own universality can only transpire through its own reflective encounters and interactions with other cultural particulars (Davis, 2006, pp. 217-220). Any act to posit a cultural hierarchy is rejected in this view of the world because that would violate the principle of the absolute contradiction. This is because when a cultural particular objectifies or universalizes itself without facing its own self-contradictions, a hierarchy begins to form where the particular sees itself as an actor who "overcomes" the contradictions within a place encased in time, thus demanding others to imitate its particularity. Since a true absolute, as Nishida argues, can only be one that descends into its own bottomless contradictions, a true global world, that which is made up of a collection of egalitarian particulars, would struggle to unfold if there is a center to all of it; therefore, a decentralized global world can only exist when the cultural particulars are cooperating towards the preclusion of a colonial or dominant order.

In the end, however, Nishida would fumble in the attempt to theorize a global world that thwarts all forms of (hidden) colonialism. In "The Principle of the New World Order" (Sekai shin-chitsujo no genri 世界新秩序の原理), as the critics would suggest, Nishida provides the rhetorical justification for Japan to assert world domination under the role and leadership of the Emperor (Arisaka \& Nishida, 1996). The language is rather ambiguous through much of Nishida's middle and later work however, which has led scholars to defend his political and cultural writings as well (despite clear hints towards cultural essentialism and reifying the Japanese nation-state). 
Nonetheless, Nishida's political and cultural philosophy would inform other thinkers of that time period, many of whom contributed to controversial symposia, such as "Overcoming Modernity" and the "World-Historical Standpoint and Japan," that are thought to lend support for Japanese colonial invasion.

But bear in mind that Nishida's philosophical resistance to Western modernity is not unique in the history of Japanese encounters with Western thought. Even prior to the Kyoto School, for instance, Japanese intellectuals such as Inoue Enryō and Inoue Tetsujirō were involved in their own forms of intellectual resistances as they contested the (Western) meaning of philosophy and religion. But what came after Nishida within the Kyoto School seems to be more in line with the sort of resistances that we see among the Frankfurt School philosophers. For instance, Nishitani Keiji (1900-1990), like his mentor Nishida, recognized the limits of Western modernity as a philosophical paradigm, but unlike Nishida, who was more interested in rebuilding epistemology by logicizing the creative formations of history, Nishitani would launch a critique of the culture of (Western) modernity from a standpoint of Buddhist emptiness (śūnyatā). While the main target for Nishida was the subject-object dichotomy constitutive of Western epistemology, which is what generated the dialectical structure of Western modernity to privilege its own cultural standpoint above the others, the main target for Nishitani was the fetishization of scientific technology and its failure to resolve the problem of nihilism.

In Religion and Nothingness (宗教亡は何か), Nishitani places the culture of Western modernity at the center of his critique. As the cultural offspring of scientific rationality, notions of unlimited progress, and materialistic conceptions of the world, modernity rapidly led to a mechanization of the world (Nishitani, 1961). In a style reminiscent of Horkheimer's critique of technological rationality where the entirety of human nature is dominated, Nishitani (1961) claims that a "process of inversion” (kankei no masashiku gyakuten 関係のまさしく逆転) has taken place as a result of the mechanization of human life, whereby the controllers of the world are now the controlled by virtue of their own pursuits for scientific rationality (p. 95). The process of mechanization for Nishitani is ultimately a cultural system of domination that robs subjectivity from finding any real meaning because the modern subject searches for meaning in the external world instead of looking inward. Within the search to find meaning in the material world, subjectivity begins to mimic the technological machine by thinking and acting out in mechanistic ways. Such sets the stage for subjectivity to be caught in a net of domination because it voluntarily gives up its own agency in exchange to be an object of mechanization for itself and others (Stromback, 2020). At the end of the day, genuine social relationships between people become shaken up in this process, replaced with egoistic pursuits, insatiable desires for mass consumption, and neverending fantasies of material progress. The nihilistic void underneath the culture of modernity remains unresolved.

Nishitani (1961) insists that the philosophical origins of mechanization can be found in Descartes's duality between subject (res cogitans) and object (res extensa) in which there is an autonomous consciousness facing a world of external matter. Plagued with anxiety and existential angst, the Cartesian subject began to question and think of itself as a substance in search of discovering its relationship with the objective world it derived from, only to find another bifurcation-except this 
time a binary between the mind and body, with two substances existing in two different worlds. The human body within the Cartesian doubt becomes conceived as belonging to the natural world, a world that is cold, lifeless, and dead-in other words, the world of mechanizationmeanwhile the ego behind the cogito takes on the substantive foundation of certainty within our pursuits for self-evident knowledge in its aim to make sense of human existence. The cogito not only gave birth to the dualities of Western modernity, but to the foundation of scientific rationality as well. As traditional religions continued to erode and secularization emerged as the dominant view of the world, the ego, as a self-centered substance, would seek to dominate the external world through scientific rationality by deploying technology in order to free itself from the brutish forces of nature (Nishitani, 1961; 2004). The natural world then becomes viewed as an infinite source of raw materials ready to be harvested and consumed for egoistic pleasures at any given moment.

On the surface it seems as if Nishitani's view of modernity is as pessimistic as many of the Frankfurt School philosophers, but such is not the case. Nishitani, in a manner similar to Nishida, summons an Asiatic solution to the problem of modernity. As a Zen Buddhist, Nishitani (1990) claims that the nihilism underlying the mechanized culture of modernity can be healed by uniting the subject-object duality at the base of our epistemologies; that is, by entering into the field of śunyatā, we can directly confront and realize the groundless nature of all reality. Within nihilism is an opening towards freedom where we will begin to look more at the world as inherently empty and thus sources of spiritual inspiration. Therefore, unlike many of the Frankfurt School thinkers who were generally unwilling to provide concrete blueprints on how to resolve the violence of modernity, Nishitani (1996) saw religion not only as a source of hope for empowering subjectivity (not unlike Horkheimer), but to provide a new chapter for human history where nihilism vanishes and one's authentic relationships with the world is reinstituted through acts of spontaneous playfulness. One can suspect correctly, however, that there is something romantic about Nishitani's vision to overcome modernity, which perhaps was the result of his own theoretical appropriation of Nietzsche and his attempt to overcome the moral systems of East (à la Buddhism) and West (à la Christianity) (as well as Nishida's philosophical mission to resolve the East-West duality). But the sub-textual image articulated in this program is that there is some cultural loss in modernity, that which needs to be restored in order to return human life to a natural state of existence. Sure, there is no antagonism against the future as often the case in romanticism, but the future is nonetheless approached by means of returning to the wisdoms of the past (and to the wisdoms of the East).

Like with all schools of thought, there is intellectual diversity within them. Kyoto School philosopher, Miki Kiyoshi, who was more Pure Land Buddhist and Marxist inspired, would seek to overcome Western modernity by correcting the dialectics of Hegel, Nishida, and Marx from a standpoint of an anthropological humanism (Stromback, 2020). Compared with Nishida and Nishitani, Miki's philosophy looks more like Western philosophy, but similar to Nishida's engagement with both Japanese and Western intellectual history, he believes in dispelling the feudal elements of Eastern culture by incorporating some principles of Western modernity within Japanese intellectual heritages in order to develop a unique philosophical standpoint that can overcome modernity (Kosaka, 2018). There are many faces and complexities to Miki's philosophical writings, but the 
resistance we see against Western modernity can be found in his ideas on recuperating religion for purposes of class struggle as well as his later writings on the principles of co-operativism and his participation in the Shōwa Kenkyūkai (Shōwa Research Association). It is worth mentioning here that Miki has been the subject of much controversy because of his involvement with the Showa Kenkyükai, which is thought to have provided the philosophical fuel for legitimizing Japanese leadership in the building of a new order in East Asia (Harrington, 2009; Iwasaki, 1998). While Miki's relationship with this political think tank is rather complicated, his writings nonetheless held Japanese culture in high regard and therefore tacitly supported the cultural stewardship of Japan (and its war machine) in its pursuit to create an East Asian bloc against Western colonialism.

Despite the controversy surrounding his legacy, Miki's philosophical resistance is rather unique in the sense that he saw modernity as plagued with problems of excess in terms of logos (language and reason) and pathos (affect/emotions). According to Miki, Western philosophy suffers from an excess of rationality (logos), exemplified by its historical celebration of liberalism, capitalism, and individualism and thereby ill-equipped to advance a concept of a "new human being" that can resolve the problem of alienation and loneliness at the heart of existence. At the same time, however, Western culture lends itself to the excess of pathos at other moments and situations, exemplified by the rise of nationalism and totalitarian societies found throughout Europe (Miki, vol. 17, 1978, p. 519). For Miki, there is an indispensable need to balance logos and pathos in order to overcome these sorts of limits and problems in Western modernity, because when united properly within the imagination, subjectivity will be more apt to voluntarily create socio-economic co-operatives that are non-coercive, arising from below (Miki, 1978). In the Mikian worldview, a mobilization of the particulars in the form of co-operatives are indeed necessary, because only then can totalitarian control be avoided in society. Miki's principles of cooperation (kyōdōshugi 協 同主義) were also meant to apply to the principles of a global world, which would foster and shape the vision of the Greater Asia Co-Prosperity Sphere-this cultural and economic unity of Asian countries and ethnicities in the attempt to establish freedom and independence from Western colonial oppression. Opposing both Western forms of subjectivity and social organization, Miki believes that such co-operatives could lead to a new form of subjectivity that fits the demands of a new historical age.

While Western modernity tends to make quick and solid distinctions between religion and the secular, the Kyoto School does not. In fact, baked within the dialectic is the view that what is secular is religious and what is religious is secular. The same roughly goes for Miki, but with some qualifications. Unlike Nishida and Nishitani who were more inspired to unite Zen Buddhism with modern rationality (despite being influenced by Pure Land Buddhism too), Miki's approach was more inspired to unite Pure Land Buddhism and Marxism. Opposing those Marxists who only saw religion as a form of false consciousness, Miki believes that we must make a distinction between “pure religion” (junsuina shūkyō 純粋な宗教) and “institutional religion” (shūkyō seido 宗教制 度): while the latter serves the economic interests of the capitalist class, the former serves the natural desire for happiness. But Miki does hold that a religion of the future must negate its other-worldly aspects and to invite those committed to the principles of pure religion to assist the proletarian movement in the fight against class domination (Miki, 1978). In Miki's account of social history, class struggle is not incompatible with the essence of religion, and in fact needs 
to be incorporated into the mythology of a society in order to give birth to a classless society. Towards this end, Miki would later write on Shinran as a disguised attempt to create a social myth based on a Marxist Pure Land, hoping to direct the action of the proletariat towards a future social-historical world that liberates all humankind (Curley, 2008; 2017).

What do we make of the Japanese revolt? Of course, there is a lot to digest here, and one may even take issue with my politicizing of the Kyoto School; but while it is true that the Kyoto School was never fully explicit about describing Western modernity as a culture of violence, the implication of their critiques against objective rationality, colonialism, and for some thinkers, capitalism, demonstrate a commitment to addressing it, nonetheless. In any case, it is important to understand the early Kyoto School thinkers as participants in the epistemological resistance to modernity, especially because their search for alternatives involves an overcoming of its problems and limitations. What we can also take from the Kyoto School critique of modernity is the same we can take from Dipesh Chakrabarty's central question articulated in Provincializing Europe: this question of how to recognize and foster historical and cultural differences in the development of modernity. For Chakrabarty (2000), the worldwide trajectory towards the imitation of Western modernity represents an inauguration of the linear temporal structure of European thought, an inauguration that is Eurocentric and provincial, because it reflects the problem of approaching history from a singular standpoint-namely, the standpoint of a secular subject (pp. 3-6). This is where the Kyoto School and those who take up the "question of modernity" within Japan are relevant. Like Chakrabarty, these Japanese intellectuals share the vision of pluralizing modernity because it is the only path that truly honors human differences. There are multiple ways for modernity to unfold, and to assume that modernity must be secular in its discursive structure can be read as a hidden attempt to insert not just Eurocentric parochialism but a new kind of colonialism (by other means). Jürgen Habermas's notion of "communicative reason," which is one fundamental view of the Frankfurt School's second generation, is an instance of this hidden imperializing because it assumes the communicative procedures of rationality to be neutral and transcendent, and that religious discourse has to be translated into this discourse before it can become reasonable (Dosdad, 2016). There is an implicit hierarchy within the secular standpoint and so any cultural particular rejecting secular modernity inherently carries the hindrance of being irrational until it becomes perceived as rational. Such is all to say that Chakrabarty and the aforementioned Japanese thinkers are just much more pluralistic and globally focused in their pursuits than other philosophical resistances, such as the Frankfurt School, because they are seeking to challenge the Eurocentric frames of philosophy by including other cultural logics within a historical trajectory that is perceived to be world-wide. Unlike the Frankfurt School, the early Kyoto School thinkers are seeking to ground their resistance and overcoming of modernity in a philosophical system of localized particulars, without the reification of a singular standpoint.

This is not to say that this school of thought is not without its problems, however. As briefly mentioned already, the Kyoto School has been criticized for its complicity with the Japanese militarist regime during WWII, because the logic of nothing at the core of the Kyoto School's epistemology, despite its usage in the attempt to pluralize global history, was co-opted by the colonial attitudes of the Japanese state (Osaki, 2019). In fact, Japanese literary critic and 
sinologist, Takeuchi Yoshimi (1910-1977) makes this issue and aporia more visible in his own critique of modernity. As a postwar intellectual who sought to revive this question of "overcoming modernity" through the method of redefining the subject-object distinction and its relationship to the notion of resistance as it applies to Asia's relationship with Europe, Takeuchi would launch a critique against Japan's blind acceptance of Western modernity, claiming that such is what drove its own history of colonial expansion leading up to the Fifteen-Year War (Calichman, 2004). According to Takeuchi, the East-West dynamic must be understood more along the lines of the master-slave dialectic (à la Hegel) and that it is important that the (i.e., Eastern) slave does not mimic or replicate the tools of the (i.e., Western) master in the act of resistance and overcoming of the East-West (i.e., master-slave) binary (2005). Informed by Chinese writer Lu Xun, and perhaps unwittingly influenced by Nishida's concept of "absolute contradiction of self-identity," a true act of resistance for Takeuchi is one where self-realization occurs through self-negation, where one is not imitating the logical structures of the Other but rather returning to one's own place of nothing through the problematization of oneself in order to fully create something new (Stromback, 2021). Although articulated later than the original symposium titled "Overcoming Modernity" in Japan, Takeuchi (2005) nonetheless discusses what is valuable about these ideas and points to how the political and philosophical implications of resisting Western modernity allows us to understand how modernization (Westernization) has generally meant a homogenization of cultural histories rather than a proliferation of true cultural and philosophical differences as a means of establishing global plurality. While Takeuchi does not completely reject the Kyoto School and its contributions, he does make explicit its failure to resolve the aporia between its own anticolonial stance and Japan's desire for colonial control. The real failure of the Kyoto School and its ideas on resistance then, as Takeuchi sees it, was the failure to think through how victims of colonialism can become colonial oppressors in a new set of socio-political arrangements. Therefore, Takeuchi, more so than the Kyoto School, provides a logic of Asian resistance that addresses the "emancipatory traps" of modernity by deploying negativity in the form of a method that refuses to cathect an Asian equivalent of liberation, a liberation that embodies any sense of a utopian connotation. What this suggests then, as far as the broader argument is concerned here, is the need to further investigate alternative epistemological standpoints that take seriously the master-slave dialectic, and the hidden victim-victimizer paradox encased therein, in the attempt to subvert modernity and thereby posit something new.

In fact, as we will see in the next section, we can also generate a critique from the perspective of Latin America towards the Kyoto School and its dependency on an epistemology of nothing as well because, as we will discuss next, such is what made its political and cultural philosophy vulnerable to state manipulation and the various institutions of power. To what extent the Kyoto School was truly participating in Japanese colonialism is another question, but the fact of the matter remains: like what Takeuchi holds against the Kyoto School, these thinkers simply did not sufficiently think through the "emancipatory traps" of modernity, such as the victim-victimizer paradox, that would provide a meaningful alternative to Western modernity. But we can also return to the insights of the Frankfurt School on this point as well. That is, there is always the possibility of Herbert Marcuse's "repressive tolerance" to arise at every turn, and so if we fail to make visible or criticize our own social, political, and material place in our epistemological investigations, then 
any project of emancipation can be re-appropriated in the service of repression and domination. Nonetheless, the central point we have to keep in mind is not only that we have an obligation to imagine epistemological alternatives to modernity, and perhaps even gesture towards some kind of cultural pluralism, but also to question whether or not these epistemological alternatives have the capacity to enact hidden forms of colonialism or violence.

\section{The Latin American Revolt: The Decolonization of Western Philosophy}

It is often said that all roads lead back to Hegel. This was seen with the Kyoto School, but this can also be seen with the Latin American revolt as well, because the method to resist and overcome Western philosophy harks back to Hegelian dialectics. To be sure, the voices of the Latin American revolt are diverse, but there is something many of those within this tradition have in common: this commitment to undermine Western modernity through a "transmodern" paradigm that represents the final moment of modernity by sublating its antithesis-postmodernity. Interestingly enough, although critical of its Turn to Terror, Hegel lauded the French Enlightenment and Revolution, which for him merited praise for initiating the principles of liberty and equality. In this sense, the discursive structure of the Latin American revolt is not only Germanic but French in its intellectual legacy. After all, the founders and proponents of the "transmodern" paradigm are directly influenced by the Francophone thinkers - as we will see. But the question is now: how do we overcome modernity and postmodernity if we are working from inside their paradigms? In order to dismantle the house of the master, do we not have to create our own toolkit in a way that does not replicate the toolkit and the house of the master-not unlike the way the Kyoto School and Takeuchi believe? For Latin American philosophers, the answer is yes. But how?

Although the term "transmodernity" (transmodernidad) was originally coined by Spanish philosopher and feminist Rosa Maria Rodriguez Magda (see Rodriguez Magda, 1989), it has been appropriated by Argentinian-born Mexican philosopher Enrique Dussel to advance a dialogue of inter-civilizational epistemologies as a strategy to displace and transcend the hidden logics of Eurocentrism engendering the violence of modernity. As just mentioned, modernity and postmodernity represent the thesis and antithesis of the Hegelian dialectic, whereas transmodernity, which negates and preserves certain elements of modernity and postmodernity, represents an ethical planetary humanism based on building a pluriversal world. Inspired by Levinas, Marxism, and the philosophy of liberation, Dussel seeks to show us not only how Eurocentrism pervades European and non-European cultures and epistemologies in ways that are not always visible, but also the ethical need for including the Other in the history of philosophical thought. In terms of the latter point, the historical tendency from Greek philosophy and on has always been to start from an ontological stance and then derive at an idealized political or cultural philosophy, but Dussel (1998), in the spirit of Levinas's critique of Being, reverses this trend in the history of philosophy by starting and ending with an ethics-first philosophy, with an ontology that is revealed from within the Other. But it should be said that Dussel is not fully on-board with the package Levinas brings to the table: politics is downplayed in Levinas's oeuvre and Latin America qua Other is completely left out of the historical picture of philosophy (Dussel, 2006, p. 87). Nonetheless, the foundation for his critical philosophy is a Levinasian affirmation of life, except that this concept is re-read through a Marxist aperture of history that positions the politicaleconomic dependencies between core and periphery as central features of his ethical critique. 
Interestingly enough, Marx holds a unique place within Dussel's philosophy of liberation because his work serves as a theoretical frame for which to understand the political-economic dependencies between core and periphery within colonial expansion but then is corrected in terms of its Eurocentric frame that assumes a linear development of political-economic history. How Dussel interweaves Marx within a Levinasian ethical critique is through hermeneutics. Contra Marxists who depart from an analysis of the commodity, Dussel re-interprets Marx by starting with Part 2 of Volume 1 in Das Kapital, where the analysis begins with the relationship between living labor and capital in the form of objectified labor (see Dussel, 1988). According to Dussel (1988), capital alone cannot be the source of surplus-value, because that would render capital as something that develops autocatalytically: rather, it is living labor that is the creative source for the valorization of capital, which means that the production of surplus-value generating profit cannot exist without subsuming the living labor located at the exterior. This is all to say that since living labor is the economic source for capital accumulation, that which exists prior to and external to capital, such should be the starting point for the Marxist critique instead of starting with the equivalency of capital and commodity. In this regard, the objectified living labor represents a transcendental, ethical critique of capitalism in Dussel's philosophy because this starting point allows for the inclusion and unmasking of the perspective of the exploited workers at the periphery, those external to capital while constituting its source for never-ending growth.

But to avoid any reduction of subjectivity to the crude categories of system-based Marxism, Dussel develops a concept of "the people" (el pueblo) as a theoretical framework that functions as the active base for decentralized knowledge production that is thought to be the core of transmodern pluralism. El pueblo, for Dussel, has a specific reference here: namely, an intersubjective formation made up of a variety of sectors, groups, and classes that have been excluded from modernity while caught up in their own local struggle for self-empowerment. For Dussel, el pueblo not only refers to oppressed groups, but also includes social elements such as,

...ethnic groups within their own language, race and religion; tribes; marginal groups which are not even a "class," simply because they have not achieved a salaried position within a weak capitalism. Therefore, strictly speaking, "pueblo" is a social block of the oppressed of a nation. From this, firstly, we cannot identify "pueblo" within a "nation" or "people." When someone says "the people of India," we must distinguish between its populist meaning (all of the nation) and its popular meaning (the social block of the oppressed) (1986, pp. 27-28; emphasis his).

Dussel's project, therefore, is one where philosophy is always done on the side of the victims of modernity in order to empower them away from a state of dependency and subordination and into a space of democratic possibilities. Towards this end, Dussel's ethical task is the cultivation of a pluriversal world in which all people live and grow in decentralized communities and develop mutual respect for cultural and philosophical diversity without fetishizing political power (fetichismo de poder) (see Dussel, 2006). The vision here is anti-utopian, because it seeks to ground power within the local, everyday action of el pueblo. What is called "the decolonization of Western philosophy" within Latin American philosophy then begins at this exterior, allying itself with the post-colonial critique, but then seeks to further delink its historical connection to Eurocentric categories through an affirmation of the epistemologies located at the periphery. 
There is one clear separation we find in Latin American philosophy vis-a-vis the Frankfurt School and the Kyoto School: while both the Frankfurt School and the Kyoto School characterize modernity more as an intellectual movement beginning in Europe, Dussel and other Latin American philosophers characterize modernity more as a geo-political event within world history that created the center-peripheral relationship we still see today. As Dussel argues (1994), there is a temptation to link the origins of modernity to Descartes's cogito, the Renaissance, or the Protestant Reformation, but in reality, modernity cannot be thought outside of the political, economic, and geographical contexts that fueled the ideology of these historical eras: that is to say, modernity must be viewed as a product that began with the Spanish colonial invasion of the Americas, meanwhile Descartes's cogito, the Renaissance, and the Protestant Reformation represent particular culminating events within the history of modernist thought (pp. 11-21). What is revealed therein is not just the Eurocentric tendencies baked into the historical narrative of modernity but the dark underside of a rational Enlightenment-particularly, its genocidal violence ignited by colonial expansion. Like Tibebu, Dussel (1994) elucidates how Kant's and Hegel's culturalist and racist views served to justify Europe's colonial invasions, a legacy that is still alive in our discursive structures: Kant thought of Asia as confined to a state of childhood and immaturity (Kindheit) while completely writing Africa and Latin America out of world history, whereas Hegel develops a dialectical structure that gives Europe a clear pre-text for becoming the missionaries of the world. In the end, both thinkers put forth a logic of colonialism that conceals the "myth of modernity" (mito de la modernidad) —namely, this framework that European thought is superior and more culturally developed than the Other (the non-Europeans) and that the Other is not only inferior, primitive, anachronistic, but culpably immature. As Dussel tells us, the "myth of modernity" is thus a paradigm that assumes the suffering of the conquered people to be a necessary and inevitable step in the path toward a greater world enlightenment, and those who resist this project are deemed responsible for the bloodshed that arose. The assumptions underlying this paradigm of thought, as Dussel (1994) maintains, serve to rationalize the irrationality of the violence of modernity by erasing the history of colonialism from the Euroamerican imagination.

Of course, we have to be careful not to think of Dussel as the progenitor of Latin American philosophy. Rather, he is merely the most important figurehead today committed to empowering the global south through intercultural dialogue. There were Latin American philosophers before Dussel, like Francisco Romero and Samuel Ramos, and there are emerging voices that will succeed Dussel, like Linda Martín Alcoff, Manuel Vargas, and Ramón Grofoguel. Now if we look at Grosfoguel's work, in particular, we find a similar commitment to the decolonization of Western philosophy. What Grosfoguel (2013) teaches us is that foundational to Western knowledge structures is "epistemic racism," which is this historically preemptive rejection or discarding of (Indigenous) philosophies that have been deemed inferior (p. 75). Why we do not see Indigenous philosophy in the academic world today is precisely because of the colonial efforts that have legitimized the extermination of the epistemologies of the global south-a process Boaventura de Sousa Santos (2014) calls "epistemicide." But nonetheless this is why "Western social theory is based on the experience of 5 countries (France, England, Germany, Italy, and the United States) that makes up only less than 12 percent of the world's population" (Grosfoguel, 2010, 
p. 31). Furthermore, Grosfoguel (2013), as borrowed from Dussel's concept of the "I conquer" (ego conquiro) (2008), remarks that this process is intellectually linked to Descartes's solipsistic consciousness: that is to say, it was not the "I think, therefore I am," but rather "I exterminate, therefore I am" that had set the stage for epistemic racism (pp. 75-77). The substantive ego constituting "I exterminate" is therefore the beginning of a secular theory of knowledge that would provide the epistemological structure for rationalizing the domination of colored, colonial, and female bodies throughout modernity.

Grosfoguel, insists that in order to understand the structural logic of epistemic racism, "we have to make a distinction between an epistemological location and a social location" (2011, p. 6). One can be socially located on the side of the oppressed within power relations, but such does not mean one is thinking from the epistemic location affirming the positions of the oppressed. The problem is that the cogito, which is assumed to be a disembodied and neutrally assumed position, hides the myth of modernity because it conceals the spatial-temporal power structures of the knowledge procedure. Since the cogito advances from a "zero-point" position (this assumed neutral position), there is an ego-politics of knowledge that becomes implicitly championed over a visibility of a geo-politics of knowledge. In the ego-politics of knowledge, which is what much of Western philosophy privileges, the subject of enunciation is erased or camouflaged, making it seem as if its point of view does not exist from within the location of power relations-hence the epistemic subject appears to have no sexuality, class, race, gender, ethnicity, or spirituality (Grosfoguel, 2012). While the ego-politics of knowledge have been made more visible in recent years with the rise of critical theory, the geo-politics of knowledge remain concealed. If a geopolitics of knowledge were to be built into and made visible within the epistemic position though, then the epistemic subject would not only recognize its own geo-political position (the social location) in the north-south axis in colonial history, but would have to integrate its own geopolitical relations into the theoretical system (the epistemological location) in order to affirm the life of the Other.

This particular point here is relevant in the sense that we can see how the modern sciences, which stem from the cogito, inherit epistemic racism. This is because the sciences began from an objectively neutral standpoint of the cogito, which masked the power structures of the epistemic subject-hence the long history of colonial participation from within the social sciences and the continuing reemergence of scientific racism in the Western world. Even scientific Marxism, which began its epistemological departure from the point of view of the European proletariat, poses a limit to thinking outside of the Eurocentrism of Western thought, because there is only an epistemological sense of class or class struggle, but no epistemological contextualization of race, gender, or religion within the relations of power (Grosfoguel, 2008; 2012). Furthermore, similar to Hegel's own epistemic racism, Marx himself subscribed to a social evolutionary model of historical reality that placed European civilization at its pinnacle. Non-Europeans were considered primitive and backwards, which depend on European modes of production and philosophical thought for its development. Without European assistance, non-Europeans would be unable to move through capitalism and socialism and then end at communism as the final stage of history. The point here is that even Marxist thought unfortunately participates in epistemic racism because it assumes 
that only the epistemologies of the Western tradition have access to universality, while nonEuropean epistemologies are not evolved enough to serve as ethics of liberation (Grosfoguel, 2012).

What is the most subversive about Latin American philosophy is its ability to recognize and build within itself all of its political positions within the production of knowledge. What the early Kyoto School thinkers failed to unmask was precisely this issue, because there is a "zero point" stance that was being sought within Nishida's and Nishitani's standpoint of nothing. Even though the Kyoto School was trying to include the epistemology of the Other in its vision of global pluralism, from a Latin American perspective, however, such a project was only thinking from the social side or social location of the oppressed and not from an epistemological standpoint that bakes its own socio-economic and geo-political position within itself (within the act of self-negation, for instance). Of course, the "zero point" aspect of the Kyoto School philosophy was not derived from Descartes's cogito, and therefore should not be subjected to the decolonial critique as such, but the fact that the Kyoto School struggled to make visible its own ties to the political position of Japan during colonial expansion represents a failure in its geo-politics of knowledge. In the end, what the Kyoto School could learn from Latin American philosophy is its ethical promise to empower the subaltern in all its forms. There are indeed parallels between the Kyoto School's pursuit of a global world and Latin American philosophy's push for a transmodern pluriverse, both of which seek to cultivate a cooperative system among cultural particulars, but the Kyoto School's strategy of negating itself in order to allow other particulars to realize themselves failed because of its "zero point" standpoint that allowed for the de facto ideology to re-assert itself unconsciously. This is all to say that while both revolts can agree that any monolithic system of knowledge, like Enlightenment rationality, must be decentralized and then built locally in order for a pluralistic global community to exist, it is Latin American philosophy at the end of the day that can be read as more subversive and calculated in its strategy to counteract the hegemonic dominance of the West.

But what about the Frankfurt School? How does the Frankfurt School fare up to the Latin American perspective? Although sympathetic to the general position of the Frankfurt School, Dussel has been critical of its overly charged critique of reason. This is because the critical theory advanced by the Frankfurt School goes too far to obscure the universal rationality existing at the base of human life. In this regard, as Dussel claims, the concept of universal rationality needs to be rescued from a critique of Enlightenment and that it is just the Eurocentric myth associated with it that needs to be negated. In pursuit of this transmodern pluriversal world, Dussel argues instead for an affirmation of reason of the (subaltern) Other, that which has been obscured by Eurocentric ideologies (1993). But what this looks like is far different than what the Frankfurt School would have in mind, especially since its critical theory is still too internally driven from Western categories and culture. In other words, a vision of alternative, underrepresented epistemologies asserting themselves in a global space as a correction of Enlightenment rationality might be rather foreign to the Frankfurt School. Whether or not the Frankfurt School fully addresses its own Eurocentric assumptions is a question for another project, but truth be told: although the Frankfurt School offers a convincing critique of reason within the context of capitalistic expansion as well as how 
reason can naturalize abuses of power, it does not go far enough in the method of self-negation to decolonial Western knowledge in the service of the Other at the periphery. If this is the real task for addressing the violence of modernity, then it might be fair to say that the Frankfurt School could benefit from the ethical methods of the Latin American critique.

\section{Conclusion: Conquering the Epistemic Violence of Modernity}

All the different epistemological resistances we discussed in this article demonstrate a commitment to resolving the problem of how to dismantle the master's house, in deciding which tools we should use, as well as the architectural problem of how to rebuild the house. For the Frankfurt School, the dismantling of the house does not involve the rejection of reason as such, but rather certain forms of Enlightenment reason-namely, objectified or technical reason, because they have been absorbed by capitalism to serve domination and oppression. Furthermore, the early Kyoto School thinkers share the concern the Frankfurt School advanced regarding rationality becoming reified in modernity: that is, the universalization of objectified rationality leads to an ahistorical ideal that will end up dominating subjectivity because all things become subordinate to it. Meanwhile, the early Kyoto School and Latin American philosophy share a concern around modernity's tendency to write off other philosophical standpoints-which prevents subaltern or marginalized groups to engage the world in a more relational and pluralistic way. Of course, in any comparative philosophical approach, we should be careful to not drown out the differences of each school of thought. For instance, Dussel and Grosfoguel are likely to ask a different set of questions than anyone from the Frankfurt School and the Kyoto School: such as, who gets access to this rationality? What is it used for? Is it used for the exclusion of the Other-against those outside of Europe and US/Canada? Or can it be used to empower subaltern identities around the world? Through these sorts of questions, as briefly discussed already, the decolonial critique is not critiquing rationality as such, but more specifically the Eurocentric frameworks that deploy reason on its behalf. If we can empower alterity with reason in order to build a more just and pluralistic world, then rationality itself is not the problem, but rather the epistemic frameworks that use reason in the service of naturalizing systems of exclusion and control.

The differences between each school of thought are perhaps their greatest strength. For instance, by the nature of the questions just mentioned, the Latin American revolt does seem to provide the most solid answers to the questions of how to dismantle the house and how to rebuild the house. But then what about the tools to rebuild the house? Is a politicized ethics to the Other sufficient? That is to say, what happens if there is a movement towards the consolidation of power in the language game of Dussel's ethical commitment to the Other, where there is a reversal of the oppressed becoming the oppressors like in George Orwell's Animal Farm? The victim-victim paradox, as discussed by Takeuchi for instance, does not seem to have much of a discussion within Dussel's or Grosfoguel's work. It is just assumed that the groups at the periphery are innocent, morally just, and reasonable, and that it is merely the oppression they experience itself that clouds these features, with a full awakening ready to transpire upon the removal of these oppressive structures. The question then becomes: does the commitment to the oppressed mean a commitment to all forms of violence used towards achieving social justice, for instance, the methods of violence used by Che Guevara? Or is the Frankfurt School's critical theory needed 
here in order to steer clear of a re-barbarization of a culture deploying reason? At some point in time, we may also have to renegotiate the various layers of the ethics-first philosophy and then move towards Nishida's basho of nothing as the fundamental ground of social history to maintain a particularized view of the world but then thread this approach through the weaves of Takeuchi's approach in order to think through the "emancipatory traps" (e.g., the victim-victimizer paradox) of modernity so as to avoid re-asserting its most hidden forms.

The goal of this article is not to provide an exhaustive description of the toolkits used to dismantle the house of the oppressors and to make explicit what the finished house would look like after reconstruction but rather to bring these different epistemological resistances into dialogue in order to expose the structural differences in the thought of each paradigm. In Karatani's radical critique of "pronounced parallax," the expectation is to make visible what is invisible to the others' thought, and so the hope is to initiate a conversation among these revolts against modernity through what is invisible to itself so that we are better prepared to engage Baudelaire's selfcritique. Assuming Baudelaire correctly identifies the violence of modernity as one where we are both victims and oppressors, I want to suggest that it is perhaps imperative for us to think through this victim-victimizer paradox not just from within each school of thought but from the exterior of each one as well, because it not only allows us to see what each revolt does not see but it allows us to make visible what is normally invisible within our own participation in the culture of modernity. Perhaps it is naïve to think we can eliminate the violence of modernity but if we can further understand the victim-victimizer paradox through the dialogue of these revolts, then we can improve the sense of how our actions and thoughts quietly reproduce the violence of the world not just through the domination of the Other but through the domination of our own subjectivity.

\section{REFERENCES}

Arisaka, Y., \& Nishida, K. (1996). The Nishida enigma: the principle of the new world order. Monumenta Nipponica 51(1), 81-105. https://doi.org/10.2307/2385317

Calichman, R. F. (2004). Takeuchi Yoshimi: displacing the west. Cornell University.

Curley, M. A. M. (2008). The Subject of history in Miki Kiyoshi's 'Shinran.”' In V. S. Hori and M. A. M. Curley (Eds.), Frontiers of Japanese philosophy 2: neglected themes and hidden variations (pp. 78-93). Nanzan Institute for Religion and Culture.

Curley, M. A. M. (2017). Pure Land, real world: modern Buddhism, Japanese leftist, and the utopian imagination. University of Hawaii Press.

Chakrabarty, D. (2000). Provincializing Europe: postcolonial thought and historical differences. Princeton University Press.

Davis, B. W. (2006). Toward a world of worlds: Nishida, the Kyoto School, and the place of cross-cultural dialogue. In J. Heisig (Ed.), Frontiers of Japanese philosophy (pp. 205-245). Nanzan Institute for Religion and Culture.

De Sousa Santos, B. (2014). Epistemologies of the south: justice against epistemicide. Routledge.

Dussel, E. (1988). Hacia un Marx desconocido: un comentario de los manuscritos del 61-63. Siglo XXI.

Dussel, E. (1993). Eurocentrism and Modernity (Introduction to the Frankfurt Lectures). Boundary 2, 20(3), 65-76. https://doi.org/10.2307/303341

Dussel, E. (1994). 1492 el encubrimiento del Otro: hacia el origen del “mito de la modernidad." Plural editores. 
Dussel, E. (1996). Toward a clarification of terms: people. In S. Amirtham and J.S. Pobee (Eds.), Theology of the people: reflections on doing theology in community (pp. 27-32). World Council of Churches.

Dussel, E. (1998). Ética de la liberación en la edad de la globalización y de la exclusión. Trotta.

Dussel, E. (2006). 'The politics' by Levinas: toward a 'critical' political philosophy. In A. Horowitz \& G. Horowitz (Eds.), Difficult justice: commentaries on Levinas and politics (pp. 78-96) University of Toronto Press.

Dussel, E. (2006). 20 tesis de política. Siglo XXI.

Dussel, E. (2008). Meditaciones anti-cartesianas: sobre el origen del anti-discurso filosófico de la modernidad. Tabula Rasa, (9), 153-197. https://revistas.unicolmayor.edu.co/index.php/tabularasa/ article/view/1497

Eagleton, T. (2003). After theory. Basic Books.

Grosfoguel, R. (2008). Hacia un pluri-versalismo transmoderno decolonial. Tabula Rasa, (9), 199-215. https:// doi.org/10.25058/20112742.345

Grosfoguel, R. (2011). Decolonizing Post-Colonial Studies and Paradigms of Political-Economy: Transmodernity, Decolonial Thinking, and Global Coloniality. TRANSMODERNITY: Journal of Peripheral Cultural Production of the Luso-Hispanic World, 1(1). http://dx.doi.org/10.5070/T411000004

Grosfoguel, R. (2010). Epistemic islamophobia and colonial social sciences. Human Architecture: Journal of the Sociology of Self-Knowledge, 8(2), 30-31. https://scholarworks.umb.edu/humanarchitecture/vol8/ iss $2 / 5 /$

Grosfoguel, R. (2012). Decolonizing Western Uni-versalisms: Decolonial Pluri-versalism from Aimé Césaire to the Zapatistas. TRANSMODERNITY: Journal of Peripheral Cultural Production of the Luso-Hispanic World, 1(3). http://dx.doi.org/10.5070/T413012884

Grosfoguel, R. (2013). The structure of knowledge in westernized universities: epistemic racism/sexism and the four genocides/epistemicides of the long $16^{\text {th }}$ century. Human Architecture: Journal of the Sociology of Self-knowledge, 11(1), 73-90. https://scholarworks.umb.edu/humanarchitecture/vol11/ iss $1 / 8 /$

Harrington, L. (2009). Miki Kiyoshi and the shōwa and the kenkyūkai: the failure of world history. Position: East Asian cultures critique, 17(1), 43-72. https://doi.org/10.1215/10679847-2008-025

Hegel, G.W.F. (1978). Philosophy of subjective spirit, Vol. 2. M.J. Petry (Ed.). Springer Nature.

Horkheimer, M. (1985). Zur Kritik der instrumentellen Vernunft. Fischer Wissenschaft.

Horkheimer, M., \& Adorno, T. (2002). Dialectic of the enlightenment: philosophical fragments. G. S. Noerr (Ed.). E. Jephcott (Trans.). Stanford University Press.

Horkheimer, M., \& Adorno, T. (2019). Begriff der Aufklärung. In Dialektik der Aufklärung: Philosophische Fragmente (pp. 9-50). Fischer Taschenbuch.

Iranzo Dosdad, Á. (2016). From the secular to the Habermasian post-secular and the forgotten dimension of time in rethinking religion and politics. Contexto Internacional, 38(3), 887-908. https://doi. org/10.1590/S0102-8529.2016380300008

Iwasaki, M. (1998). Desire for a poietic metasubject: Miki Kiyoshi's technology theory. In Y. Yamanouchi, J. V. Koschmann, \& R. Narta (Eds.), Total war and 'modernization'. (pp. 159-180). Cornell University.

Karatani, K. (2003). Transcritique: On Kant and Marx. S. Kohso (Trans.). The MIT Press. 
Kosaka, K. (2018). The Kyoto school and the issue of 'overcoming modernity.' In M. Fujita (Ed.), R. Chapeskie \& J. Krummel (Trans.), The philosophy of the Kyoto school (pp. 233-251). Springer Nature Singapore.

Marcuse, H. (1965). Repressive tolerance. In R. P. Wolff \& B. Moore (Eds.), A critique of pure tolerance (pp. 81-123). Beacon Press.

Marcuse, H. (1969). An essay on liberation. Beacon Press.

Marcuse, H. (1991). One dimensional man. Beacon Press.

Miki, K. (1978). Miki Kiyoshi Zenshū. 三木清全集 [The Complete Works of Miki Kiyoshi]. Shōten

Murthy, V. (2014). Critical theories of modernity. In P. Duara, V. Murthy, \& A. Sartori (Eds.), A companion to global historical thought (pp. 228-241). Wiley and Sons.

Nishida, K. (1965). Nishida Kitarō Zenshū. 西田幾多郎全集 [Complete works of Nishida Kitarō]. Iwanami shōten.

Nishitani, K. (1961). Shūkyō towa nanika: shūkyō ronshū. 宗教とは何か: 宗教論集 1 [What is Religion?: Essay Collection on Religion 1]. Kokusai nihon kenkyūjyo.

Nishitani, K. (1990). The self-overcoming of nihilism. G. Parkes \& S. Aihara (Trans.). State University of New York Press.

Nishitani, K. (1996). Shūkyō to hi-shūkyō no aida. 宗教と非宗教の間 [Between Religion and Non-Religion]. Iwanami shōten

Nishitani, K. (2004). The awakening of self in Buddhism. In F. Franck (Ed.), the Buddha eye: an anthology of the Kyoto school and its contemporaries (pp. 11-20). World Wisdom Publications.

Osaki, H. (2019). Nothingness in the heart of empire: the moral and political philosophy of the Kyoto school in imperial Japan. State University of New York Press.

Ott, M. (2001). Max Horkheimer's critical theory of religion. University Press of America.

Rodriguez, R. M. (1989). Sonrisa de saturno: hacia una teoría transmoderna. Editorial Anthropos.

Sanbonmatsu, J. (2004). The postmodern prince: critical theory, left strategy, and the making of a new political subject. Monthly Review Press.

Sanyal, D. (2006). The violence of modernity: Baudelaire, irony, and the politics of form. Johns Hopkins University Press.

Stromback, D. (2020). Miki Kiyoshi and the overcoming of German and Japanese philosophy. European Journal of Japanese Philosophy 5, 103-143.

Stromback, D. (2020). Nishida's philosophical resistance to Western constructions of religion. Journal of Japanese Philosophy 6, 63-94. https://doi.org/10.1353/jjp.2020.0003

Stromback, D. (2020). Philosophy beyond mechanization: critiquing economic liberalism through Nishitani Keiji's critique of modernity. Buddhist-Christian Studies 40, 223-252. https://doi.org/10.1353/ bcs.2020.0013

Stromback, D. (2021). What exactly is Takeuchi Yoshimi's logic of Asian resistance? International Journal of Asian Studies, 1-16. https://doi.org/10.1017/S1479591421000486

Takahiro, N. (2011). 'Asia' as a 'relational' concept from the perspective of Japanese Marxist philosophers: Hiromatsu Wataru, Miki Kiyoshi, \& Tosaka Jun. In Practicing philosophy between Japan and China (pp. 115-128). UTCP. 
Takeuchi, Y. (2005). What is modernity? Writings of Takeuchi Yoshimi. Richard F. Calichman (Trans.). Columbia University Press.

Tibebu, T. (2011). Hegel and the third world: the making of eurocentrism in the world. Syracuse University Press.

Whitebook, J. (2006). The marriage of Marx and Freud: critical theory and psychoanalysis. In F. Rush (ed.), The Cambridge companion to critical theory (pp. 74-102). Cambridge University Press.

Zimmermann, M. (2006). Nishida's 'self-identity of absolute contradiction' and Hegel: Absolute negation and dialectics. In J. Heisig (ed.), Frontiers of Japanese philosophy vol 1 (pp. 184-204). Nanzan Institute for Religion and Culture.

\section{Author}

Dennis Stromback. Earned his undergraduate and master's in cultural anthropology at the University of Minnesota and received his PhD from the Department of Religion in 2019 at Temple University in Philadelphia. He is an editorial assistant for the Journal of Japanese Philosophy. 